\section{PEMANFAATAN LIMBAH KAIN \\ BATIK \\ UNTUK PENGEMBANGAN PRODUK AKSESORIS FASHION}

Toufiq Panji Wisesa, S.Ds., M.Sn

Hari Nugraha, M.Ds

Program Studi Desain Produk

Universitas Pembangunan Jaya

Email:t_wisesa@gmail.com

\section{Abstrak}

Salah satu fenomena permasalahan lingkungan saat ini adalah menumpuknya limbah yang tidak dapat terurai oleh alam seperti limbah sampah yang berbahan dasar sintetis seperti plastik dan kain. Salah satu usaha menanggulangi permasalahan lingkungan ini adalah dengan menghadirkan produk eco-fashion, salah satunya penggunaan kembali sisa produksi kain batik sebagai material utama. Penelitian ini fokus pada eksperimen teknik pembuatan produk aksesoris fashion dengan memanfaatkan limbah kain batik yang tersedia pada industri kecil.

Kata kunci : limbah kain batik, aksesoris fashion, eskperimen

\section{Abstrak}

One of the environmental problems today is the accumulation of waste that can not be decomposed by nature such as waste bins are made from synthetic plastic and fabric.
One solution to address these environmental problems is to bring eco - fashion products, which reuse leftover production of batik cloth as the main material . This study focuses on the experimental technique of making fashion accessories products by utilizing waste batik fabrics are available in small industry.

Keywords: waste of batik fabric,fashion accesories, experiment

\section{PENDAHULUAN}

\subsection{Latar Belakang}

Batik merupakan kerajinan yang memiliki nilai seni tinggi dan telah menjadi bagian dari budaya Indonesia (khususnya Jawa) sejak lama. Perempuan-perempuan Jawa di masa lampau menjadikan keterampilan mereka dalam membatik sebagai mata pencaharian, sehingga di masa lalu pekerjaan membatik adalah pekerjaan eksklusif perempuan sampai ditemukannya "Batik Cap" yang memungkinkan masuknya laki-laki ke dalam bidang ini. Ada beberapa pengecualian bagi fenomena ini, yaitu batik pesisir yang memiliki garis maskulin seperti yang bisa dilihat pada corak "Mega Mendung", dimana di beberapa daerah pesisir pekerjaan membatik adalah lazim bagi kaum lelaki. 
Ragam corak dan warna Batik dipengaruhi oleh berbagai pengaruh asing. Awalnya, batik memiliki ragam corak dan warna yang terbatas, dan beberapa corak hanya boleh dipakai oleh kalangan tertentu. Namun batik pesisir menyerap berbagai pengaruh luar, seperti para pedagang asing dan juga pada akhirnya, para penjajah. Warna-warna cerah seperti merah dipopulerkan oleh orang Tionghoa, yang juga mempopulerkan corak phoenix. Bangsa penjajah Eropa juga mengambil minat kepada batik, dan hasilnya adalah corak bebungaan yang sebelumnya tidak dikenal (seperti bunga tulip) dan juga benda-benda yang dibawa oleh penjajah (gedung atau kereta kuda), termasuk juga warna-warna kesukaan mereka seperti warna biru. Batik tradisonal tetap mempertahankan coraknya, dan masih dipakai dalam upacaraupacara adat, karena biasanya masingmasing corak memiliki perlambangan masing-masing.

Daerah penghasil kain batik yang paling menonjol di Indonesia ialah pulau Jawa dengan pusat-pusatnya antara lain, Yogyakarta, Surakarta, Pekalongan, Cirebon, Tasikmalaya, dan Garut. Salah satu penghasil batik di Jawa barat yang cukup terkenal dan sampai saat ini masih menghasilkan kain batik yang memiliki corak dan wama yang khas adalah Garut. Untuk mengetahui perkembangan batik Garut yang berkaitan dengan motif; warna, bahan, fungsi dan pemasarannya perlu dilakukan suatu kajian teoretik maupun empirik.

Bentuk motif batik Garut merupakan cerminan dan kehidupan sosial budaya, falsafah hidup, dan adat-istiadat orang Sunda. Beberapa perwujudan batik Garut secara visual dapat digambarkan melalui motif dan warnanya. Berdasarkan pemikiran yang melatar belakangi penciptaan batik Garut, maka motif-motif yang dihadirkan berbentuk geometrik sebagai ciri khas ragam hiasnya. Bentuk-bentuk lain dan motif batik Garut adalah flora dan fauna. Bentuk geometrik umumnya mengarah ke garis diagonal dan bentuk kawung atau belah ketupat.

Selanjutnya menurut Djoemena (1990), batik Garut memiliki warna yang khas yaitu warna gumading, biru tua, merah tua, hijau tua, coklat kekuningan dan ungu tua. Batik Garut pun mengenal warna sogan (coklat), tetapi warna sogan pada batik Garut sama dengan warna sogan pada batik di Solo atau Yogyakarta. Pada batik Garut warna sogannya ialah warna coklat muda kekuningan dan warna tersebut menajdi ciri khas yang kuat dari batik Garut.

Proses daur ulang limbah khususnya kain perca batik dapat berdampak positif bagi industri kreatif, yaitu membawa nilai lokal yang manjadi ciri khas sebuah produk. 
Limbah kain perca batik dapat ditemui di hampir seluruh industri batik Indonesia, khusus kain berjenis katun adalah jumlah yang paling banyak dikarenakan harga bahan katun lebih murah dibandingkan bahan lainnya dalam batik seperti kain sutra. Pengolahan limbah kain perca ini memang sudah banyak dilakukan oleh beberapa pengrajin, namun kurangnya inovasi desain dan variasi tehnik produksi menjadikan produk ini memiliki pasar yang terbatas dan cenderung tidak berkembang. Pengolahan limbah kain perca secara konvensional, seperti memilih potongan kain lalu menggabungkannya menjadikan produk tersebut tidak berkembang menjadi produk yang inovatif, karena aspek fungsi pakai saja yang diutamakan.

\subsection{Rumusan Masalah}

Penelitian ini fokus terhadap eksplorasi dan pengembangan potensi limbah kain perca batik sehingga memiliki nilai produk yang tinggi dan membawa dampak yang sangat besar bagi industri fashion. Nilai produk didesain memanfaatkan berbagai macam penggayaan sehingga menjadi produk yang diminati pasar saat ini. Perpaduan nilai tradisi pada batik dan pengembangan desain akan menjadi alternatif produk batik yang berasal dari daur ulang limbah.

\subsection{Tujuan Penulisan}

Penelitian ini bertujuan juga untuk pengembangan pemanfaatan dan pengolahan limbah kain batik dengan penerapan teknik dan penggayaan yang sesuai dengan perkembangan trend saat ini. Dengan pelaksanaan penelitian ini, diharapkan akan menghasilkan temuan baru yang dapat digunakan oleh lingkungan akademis maupun untuk masyarakat sekitar terutama untuk industri kecil.

Adapun manfaat dari hasil penelitian ini adalah mampu melestarikan dan menumbuhkembangkan tradisi pembuatan kerajinan aksesoris fashion di kalangan masyarakat Garut dan sekitarnya. Selain itu penelitian ini juga bermanfaat sebagai pilot project industri kecil di wilayah Garut dan sekitarnya dalam hal penerapan teknik dan model untuk merancang aksesoris fashion. Penelitian ini juga akan menghasilkan diversifikasi desain dari produk fashion dan menambah kualitas produk sehingga dapat diterima oleh pasar yang lebih luas.

\section{TINJAUAN TEORITIS}

\subsection{Batik Garutan}

Daerah penghasil kain batik yang paling menonjol di Indonesia ialah pulau Jawa dengan pusat-pusatnya antara lain, Yogyakarta, Surakarta, Pekalongan, Cirebon, Tasikmalaya, dan Garut. Salah satu 
penghasil batik di Jawa barat yang cukup terkenal dan sampai saat ini masih menghasilkan kain batik yang memiliki corak dan wama yang khas adalah Garut. Bentuk motif batik Garut merupakan cerminan dan kehidupan sosial budaya, falsafah hidup, dan adat-istiadat orang Sunda.Beberapa perwujudan batik Garut secara visual dapat digambarkan melalui motif dan warnanya.Berdasarkan pemikiran yang melatar belakangi penciptaan batik Garut, maka motif-motif yang dihadirkan berbentuk geometrik sebagai ciri khas ragam hiasnya. Bentuk-bentuk lain dan motif batik Garut adalah flora dan fauna. Bentuk geometrik umumnya mengarah ke garis diagonal dan bentuk kawung atau belah ketupat.

Selanjutnya menurut Djoemena (1990), batik Garut memiliki warna yang khas yaitu warna gumading, biru tua, merah tua, hijau tua, coklat kekuningan dan ungu tua. Batik Garut pun mengenal warna sogan (coklat), tetapi warna sogan pada batik Garut sama dengan warna sogan pada batik di Solo atau Yogyakarta. Pada batik Garut warna sogannya ialah warna coklat muda kekuningan dan warna tersebut menajdi ciri khas yang kuat dari batik Garut.
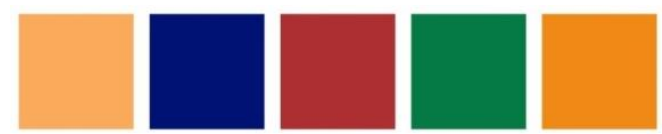

Gambar 1 (Ragam warna batik Garutan)

Sumber: Peneliti
Dalam jurnal wacana senirupa berjudul Batik Garut Kajian Bentuk dan Warna (2003), beberapa perwujudan batik Garut secara visual dapat digambarkan melalui motif dan warnanya sebagai berikut:

\subsection{Bentuk Dasar Geometrik}

Ragam hias dengan bentuk dasar geometrik memiliki ciri kerangka dasar berbentuk ilmu ukur, seperti segi empat dan segi empat panjang yang tersusun dalam garis miring diagonal. Motif-motif yang termasuk pada kelompok ini adalah lereng, umumnya pengembangan dari motif lereng arbai yang lama, pengembangan motif lama lereng barong, dan pengembangan lama lereng kaktus. Tata warna batik Garut pada umumnya warna batik Garut asli dengan latar yang khas, yaitu krem (pulas gumading - Sunda) dan sogan. Di samping itu terdapat warna-warna lain seperti biru tua, merah tua, coklat dan ungu tua.

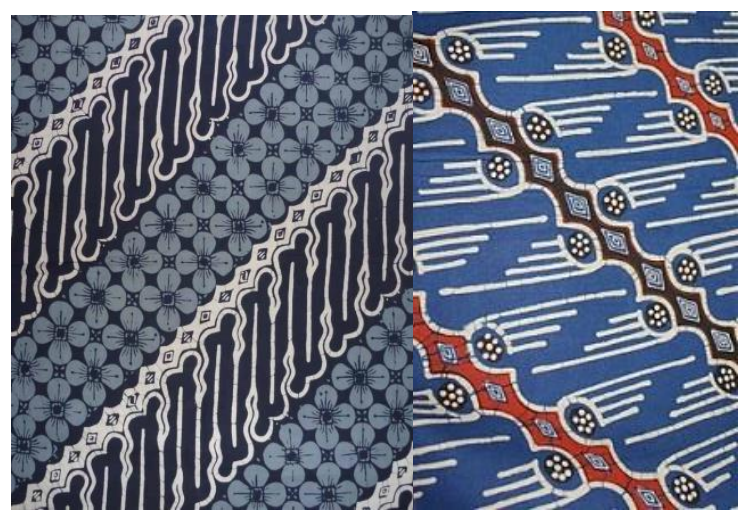

Gambar 1.1-2 (Ragam hias bentuk dasar geometrik)

Sumber: skertsabudaya.blogspot.com 


\subsection{Bentuk Dasar Geometrik dengan Unsur Fauna}

Ciri khas visual dari bentuk ragam hiasnya yaitu selain mengarah dan membentuk garis diagonal, terdapat bentuk kupu $\neg$ kupu yang terpengaruh dari jenis batik daerah lain. Warna khas Garutan asli seperti krem tetap diperhatikan yang digabungkan dengan warna coklat muda dan tua, dan biru muda.

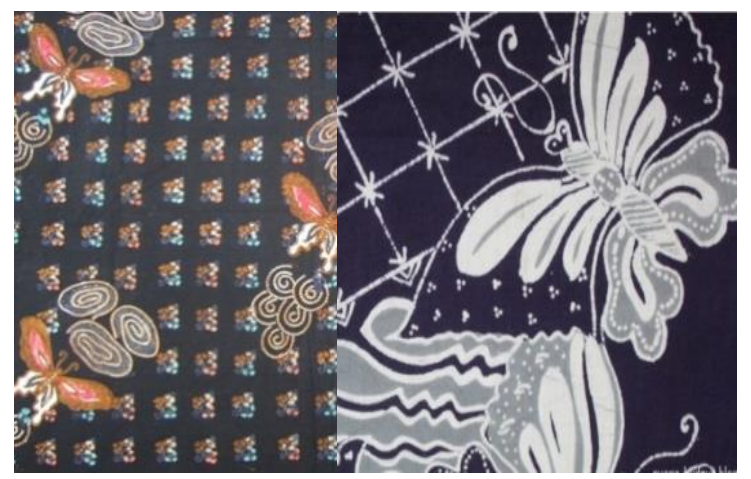

Gambar 2 (Ragam hias bentuk dasar geometric dengan unsur fauna)

Sumber: sketsabudaya.blogspot.com

\subsection{Bentuk Dasar Geometrik dengan Unsur Flora}

Secara visual, motif utama dari jenis batik ini yaitu unsur flora yang berbentuk bunga, daun, dan tangkai. Pada ragam hias menunjukan adanya perpaduan motif batik Jawa Tengah dan Madura dengan batik Garutan. Hal tersebut diperkuat oleh warna dasar krem sebagai warna asli dengan warna Garutan klewr, yaitu warna cerah dari batik pesisir seperti Pekalongan dan Madura.

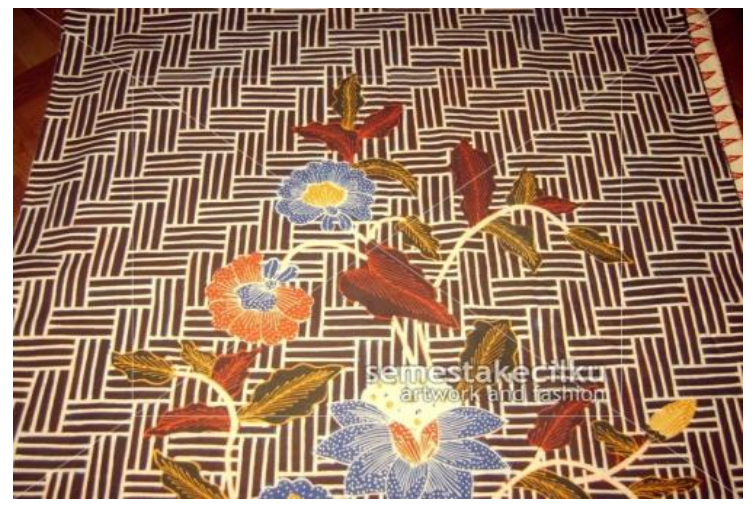

Gambar 3 (Ragam hias bentuk dasar geometric dengan unsur flora)

Sumber: faisalfateew.wordpress.com

Untuk melihat varian jenis batik Garutan, tim peneliti melakukan survey ke beberapa UKM Batik Garutan yang memproduksi kain batik. Salah satunya yaitu Batik RM yang terletak di J1 Papandayan no 54, Garut. Beberapa produk yang dihasilkan yaitu jenis batik tulis dan cap dengan varian produk busana seperti kain, kemeja, dan busana wanita. Batik RM adalah industry batik rumahan yang memproduksi batik tulis dari bahan sutera dan batik cap dari bahan katun. Pada proses produksinya batik RM memperkerjakan sekitar 8 orang pengrajin dan sebagian besar diantara mereka masih ada hubungan saudara. Teknik tradisional membatik yang diterapkan juga ditularkan secara turun menurun sehingga kualitas batik RM terus terjaga dengan baik. Untuk satu jenis batik tulis diselesaikan dalam kurun waktu antara 3 minggu sampai lbulan, tergantung tingkat kerumitan dari motif yang diaplikasikan. 
Batik RM termasuk produk yang cukup menonjol di kota Garut karena produktifitas pengrajinnya yang konsisten dalam menghasilkan batik , disamping itu seringkali tempat ini dijadikan acara kunjungan tamu untuk melihat proses membatik secara langsung karena lokasinya yang cukup strategis. Untuk jenis batik cap batik RM mengerjakannya setiap 1 minggu sekali, dikarenakan prosesnya yang tidak membutuhkan waktu yang tidak lama dibandingkan pengerjaan batik tulis. Kuantitas produksi batik cap dalam sebulan dapat menghasilkan sekitar 30 helai kain dengan 6 varian motif. Selanjutnya untuk memproduksi busana batik seperti kemeja, batik RM memakai jasa penjahit diluar yang kemudian dijual dalam butik batik RM. Dari sisa produksi busana inilah selanjutnya penelti akan melakukan pengembangan produk aksesoris fashion dan sebagian besar limbah berasal dari batik jenis cap karena harganya yang lebih murah menjadikan produk ini lebih diminati pasar menengah.



Gambar : 4 (Lokasi dan berbagai hasil produk batik RM)

Sumber: Dokumentasi Peneliti
Proses pembuatan batik cap tidak seperti proses pembuatan batik tulis yang dalam proses pembuatannya menggunakan canting, pada proses pembuatan batik cap alat yang digunakan yaitu berupa cap stempel besar yang terbuat dari tembaga, dimana permukaan tembaga tersebut sudah didesain dengan bentuk motif tertentu. Biasanya dimensi bidang cap yaitu $20 \mathrm{~cm}$ x $20 \mathrm{~cm}$, berikut ini gambaran proses pembuatan batik cap di lokasi Batik RM, Garut:

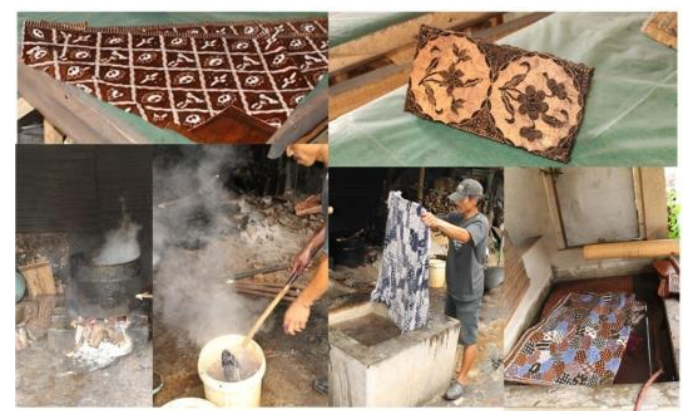

Gambar : 5 (Proses pembuatan batik cap)

Sumber: Dokumentasi Peneliti

Hal yang penting untuk dapat dikaji dan dikembangkan dari Batik RM untuk penelitian ini yaitu:

a. Mengetahui perkembangan batik dari segi jenis bahan dan visual (warna dan motif)

b. Mengetahui cara pembuatan Batik secara tradisional sehingga dapat memberikan nilai lebih pada hasil produk 


\section{ANALISA DATA}

\subsection{Limbah Tekstil}

Kata 'textile' berasal dari bahasa Latin yaitu kata texere, dimana istilah tersbut digunakan oleh bangsa Roma yang mengartikannya 'to wave', 'to braid', atau 'to construct'. Tekstil merupakan segala sesuatu yang berhubungan erat dengan serat.Sedangkan serat sendiri erat juga kaitannya dengan jahitan, rajutan dan bordir (reka latar dan reka rakit) dan pakaian itu sendiri secara umum merupakan bentuk terakhir dari serat yang mengalami beberapa tahap produksi (sumber: Words Textiles by John Gillow).

Selanjutnya, kata limbah yang diterjemahkan kedalam bahasa inggrisnya menjadi waste, dalam kamus Webster,s Collegiate Dictonary 2004'...4 a: damaged,devective, or superfluous material produced by manifacturing process: as (1) : material rejected during a textile manufacturing process...' telah rusak, tidak sempurna, atau material produksi yang tidak diperlukan sepanjang proses manufaktur sebagai (1): Material yang ditolak selama proses manufaktur tekstil berlangsung...'Di dalam Kamus Besar Bahasa Indonesia, Edisi ke-3, tahun 2001, Balai Pustaka, arti limbah adalah sisa proses produksi Dari kedua sumber limbah berarti sisa material proses produksi pada sebuah industri atau manufaktur.
Jenis limbah tekstil yang seringkali ditemui dibagi 3 jenis, yaitu:

- Raw Material atau kimia tekstil

- Sisa potongan kain

- Limbah benang, dan

- Busana yang sudah tidak terpakai

Adapun potensi limbah jika dikaitkan dengan proses kreatif dan pengembangan produk, adalah:

- Dapat mengurangi ketergantungan bangsa kita terhadap bahan baku untuk pakaian yang selalu diimpor.

- Dapat menciptakan produk yang ramah lingkugan tanpa meninggalkan nilai produk itu sendiri, yaitu rasional, emosional dan fungsional.

- Dapat membangun kesadaran akan pemahaman pengelolaan lingkungan dan masyarakat dalam memperlakukan limbah sebagai pemikiran sekaligus diimplementasikan secara langsung dalam kehidupan sehari-hari kepada masyarakat.

- Memberikan kontribusi pada bidang desain produk /kriya dalam mengembangkan potensi pengolahan limbah.

\subsection{Pemanfaatan limbah sebagai inovasi yang berkelanjutan}

Inovasi berkelanjutan tidak harus selalu berkaitan dengan teknologi, tetapi mengenai berpikir dan bertindak kembali bagaimana mencari titik temu antara kebutuhan yang terus meningkat dan dampak yang buruk bagi lingkungan dan sosial. Di Indonesia 
fenomena ini terus menjadi masalah yang cukup serius, di beberapa kasus industri menengah sampai besar para pengelola belum total memikirkan dampak dari limbah ini kepada masyarakat sekitar sehingga perlu dipikirkan pendekatan kreatif untuk menanggulangi masalah ini. Inovasi berkelanjutan harus berperan terutama bagi pelaku kreatif agar didorong untuk menciptakan produk-produk unggulan yang berasal dari limbah namun ramah lingkungan sehingga dapat diterima di pasar yang lebih luas. Di beberapa negara maju pengalihan material sudah diaplikasikan oleh beberapa industri tekstil diantaranya:

a. Mereduksi pengggunaan packaging hingga $75 \%$

b. Bahan polyester digantikan dengan bahan katun

c. Cat berbasis air digunakan untuk sablon, dan

d. Peningkatan keamanan dan kenyamanan kerja di pabrik

Untuk industri kecil sampai menengah, cara paling sederhana untuk menghasilkan produk ramah lingkungan dapat diperoleh dengan materi daur ulang. Daur ulang adalah proses untuk menjadikan suatu bahan bekas menjadi bahan baru dengan tujuan mencegah adanya sampah yang sebenarnya dapat menjadi sesuatu yang berguna, mengurangi penggunaan bahan baku yang baru, mengurangi penggunaan energi, mengurangi polusi, kerusakan lahan, dan emisi gas rumah kaca jika dibandingkan dengan proses pembuatan barang baru.

Akhir-akhir ini juga muncul istilah Eco Fashion dan telah menjadi pengaruh yang sangat besar dalam trend fashion dunia dan merupakan pernyataan terdepan dari komunitas fashion di negara-negara maju. Eco Fashion merupakan prduk fashion yang di produksi menggunakan produk - produk ramah lingkungan dalam prosesnya. Klasifikasi eco fashion diantaranya adalah organic materials, recycle and reuse, sustainable, craft/artisan, donate, dan fair trade. Untuk penelitian ini aspek yang paling dominan adalah recycle and reuse yang berarti menggunakan bahan-bahan lama untuk di daur ulang menjadi produk baru. Selanjutnya craft atau artisan juga menjadi aspek utama yang berarti menggunakan metode tradisi agar nilai lokal yang terkandung pada produk tetap terjaga.

\subsection{Pemanfaatan Limbah Tekstil Oleh} Dr. Dian Widiawati dan Esti Siti Gandana, M.Ds

Dari hasil penelitian yang dilakukan oleh Dr. Dian Widiawati dan Esti Siti Gandana, M.Ds hasil eksperimen struktur konstruksi rajut ternyata memerlukan spesifikasi benang untuk setiap aplikasi produk fashion. Pemilahan bahan baku ternyata menjadi aspek penting dalam eksplorasi, nyatanya 
tidak semua limbah bahan baku dapat sesuai dengan pembentukan untuk aplikasi produk. Hal ini bergantung pada jenis teknik rajut yang dipakai dan berikut ini adalah analisa dari hasil eksperimen yang telah dilakukan:

Permasalahannya produk fashion yang terbuat dari teknik rajut sudah cukup berkembang di pasaran lokal maupun internasional. Namun penerapannya masih dominan pada produk busana seperti baju dan sweater,, variasi yang ditawarkan pun bervariatif dari segi warna, struktur, dan model. Proses produksi juga sebagian besar menggunankan mesin rajut yang cenderung kaku dan monoton dibandingkan produk buatan tangan atau

kombinasi mesin yang secara teknis masih dapat diolah untuk lebih menonjolkan sisi estetika.

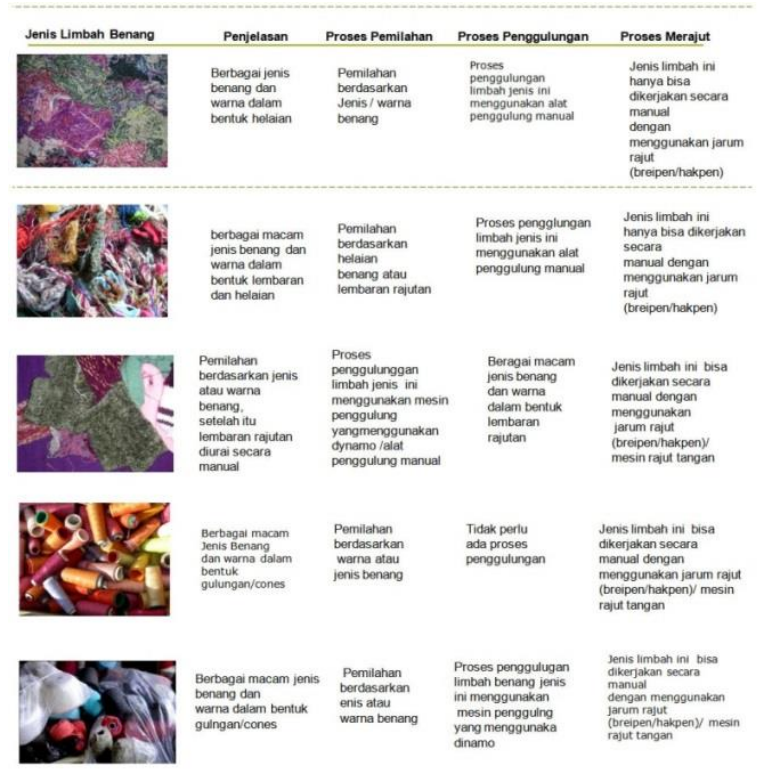

Gambar : 6 (Tabel analisa bahan baku limbah )
Sumber: Dr Dian Widiawati dan Esti Siti Gandana, M.Ds

\subsection{Arah Penelitian Produk dari Limbah Kain Batik}

Dari analisa hasil penelitian sebelumnya yang pernah dilakukan dalam pengolahan limbah tekstil, hasil penelitian yang dijadikan referensi yaitu yang dilakukan oleh Dr Dian Widiawati dan Esti Siti Amanah Gandana, M.Ds. Hasil kesimpulan dari analisa tersebut kemudian dirumuskan untuk mencari sebuah alternatif teknik pemanfaatan limbah kain sampai menjadi produk aksesoris fashion yang baik, kemudian teknik pengolahan limbah kain batik selanjutnya akan diuji dengan menggunakan metode eksperimental.

Peneliti juga memanfaatkan mitra workshop dalam merealisasikan produk aksesoris yang dituju. Mitra usaha yang dipilih adalah Ayunan Indonesia yang beralamat di Jalan Karang Layung no 25, kota Bandung. Ayunan Indonesia telah berdiri semenjak tahun 2012 dengan satu orang pemilik sekaligus desainer bernama Amalia W dan dibantu dengan dua orang asisten penjahit. Produk yang dihasilkan diantaranya berupa aksesoris fashion, busana anak-anak, bantal, dan boneka yang sebagian besar memanfaatkan kain batik Garutan sebagai andalan ciri khas produknya. 
Pertimbangan peneliti memilih workshop ini adalah:

1. Kualitasnya pengerjaan yang baik

2. Sebagian besar memanfaatkan pekerjaan tangan

3. Pemilik sangat kooperatif untuk ikut serta mengembangkan produk penelitian

4. Fleksibilitas waktu

5. Tersedia bahan baku limbah kain batik Garutan sisa dari hasil produksi

Untuk membatasi rencana produk, peneliti memanfaatkan referensi visual sebagai produk pembanding dan analisa trend produk aksesoris yang memanfaatkan limbah dari benda yang tak terpakai. Hal ini dipicu oleh isu pemanasan global dimana setiap manusia sudah seharusnya semakin menjaga kelestarian bumi dengan cara-cara yang arif dan bijak salah satunya adalah konsep reuse atau pemanfaatan kembali material dalam lingkup desain. Pada gambar dibawah ini merupakan contoh produk aksesoris fashion eksperimental, dimana pemanfaatan limbah dalam industri fashion telah menjadi trend yang diminati saat ini khususnya di negara Barat.

Selanjutnya pemilihan eksperimen yang akan dilakukan yaitu penerapan teknik patchwork dan knot (simpul) dengan varian aksesoris tambahan, kemudian dari hasil eksperimen tersebut kemudian akan dilanjutkan ke proses desain untuk diaplikasikan menjadi sebuah aksesoris fashion dengan informasi teknik yang dapat diterapkan oleh industri kecil sampai menengah.

Berikut ini rincian tahapan penelitian yang akan dilakukan yaitu sebagai berikut :

1. Eksperimen dan Pra Desain

- Pemilihan jenis kain, motif dan warna

- Proses pemilahan bahan untuk struktur desain

- Proses penggabungan teknik knot, patchwork, dan winding

- Analisis hasil eksperimen

2. Proses Desain

- Pembuatan gambar desain

- Reka bahan penunjang aksesoris

- Perakitan produk

3. Implementasi Produk

- Merencanakan mengikuti pameran produk

- Pembuatan beberapa duplikasi prototip

- Analisa respon pasar

\subsection{Proses Eksperimen Rancangan Produk}

Sebelum masuk dalam tahapan eksperimen, hasil dari pengambilan limbah kain batik harus disortir terlebih dahulu agar dapat diklasifikasikan menurut: bahan, warna, dan motif. Dalam pengerjaannya, pemilihan kain 
diputuskan pada kain batik jenis katun. Kelebihan kain katun adalah daya serap terhadap air tinggi, sehingga jika digunakan berefek dingin pada saat dipakai, kain ini mempunyai kemampuan yang lebih bagus untuk menyesuaikan suhu di dalam dan luar kain, bahan terasa dingin dan lentur, menyerap keringat, pakaian atau kain akan rusak bila direndam lebih dari 2 jam, noda dari makanan dan minyak akan mudah hilang dengan menggunakan detergen, bisa dicuci atau di dry clean, rentan terhadap jamur.

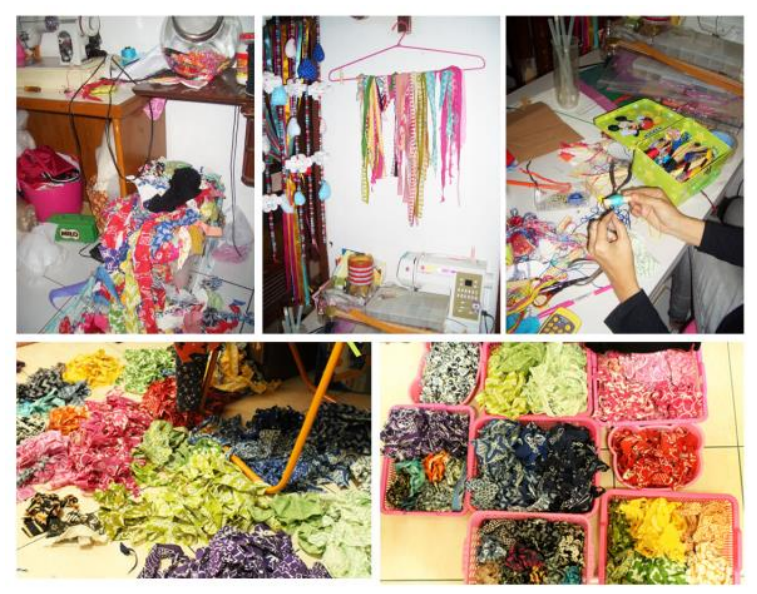

Gambar: 7 (Tahap pemilihan warna dari sisa kain produksi )

Sumber: Dokumentasi Peneliti

Dari asal kata cotton (kapas), kain ini dibuat dari serat tanaman kapas. kain yang menggunakan bahan dasar ini biasanya berefek dingin jika digunakan, dan ketebalannya (gramasi) pun bermacammacam berdasar konstruksi kain dan ketebalan benang, ini juga yang menentukan rapat/renggangnya kain.Selain kelebihan kain katun, ciri khas batik Garutan modern lebih terlihat pada kain ini dimana aplikasi warna yang lebih cerah dengan paduan motif yang kontras. Berikut gambar proses pemilahan limbah kain batik

\subsection{Tahap Konsep dan Sketsa Desain}

Dalam tahap ini, peneliti mengawali membuat peta pemikiran eksperimen yang berisi mengenai tahap alur desain, produksi, dan pasar. Ketiga hal tersebut menjadi parameter utama dalam pengembangan desain, selain itu bagan ini juga bertujuan agar masalah penelitian tetap pada alur yang telah ditentukan.

Peneliti mengawali dari tahap desain awal yang didasarkan fokus pada teknik patchwork dan knot. Teknik patchwork merupakan teknik yang menggabungkan potongan-potongan kain perca satu dengan yang lainnya dan memiliki motif atau warna yang berbeda-beda lalu menjadi suatu bentuk baru. Patchwork adalah seni tradisional yang pertama kali ditemukan di Amerika Serikat, ciri khas teknik ini adalah memanfaatkan kembali sisa-sisa dari kain yang rusak atau tidak bisa dipakai dengan mengguntingnya lalu dijadikan bentuk yang dapat dimanfaatkan kembali menjadi visual permukaan yang baru. Sedangkan teknik knot adalah teknik simpul yang biasa diaplikasikan pada jenis macrame . yang berarti teknik menyimpul dimana kedua 
ujung benang saling terkunci satu sama lain. Peneliti akan mengaplikasikan beberapa jenis simpul dasar melalui pendekatan jenis macramé ini pada desain aksesoris fashion.

Proses selanjutnya adalah tahapan sketsa desain sebagai rencana bentuk akhir produk, dalam prosesnya peneliti melakukan visualisasi gambar manual disertai konsultasi berkala dengan workshop Ayunan Indonesia. Gambar desain ditujukan sebagai tolak ukur pengembangan ragam desain beserta aplikasi teknik dan pemakaian aksesoris tambahan. Penerapan eksperimen akan diaplikasikan pada jenis aksesoris pelengkap seperti kalung, gelang dan sirkam.

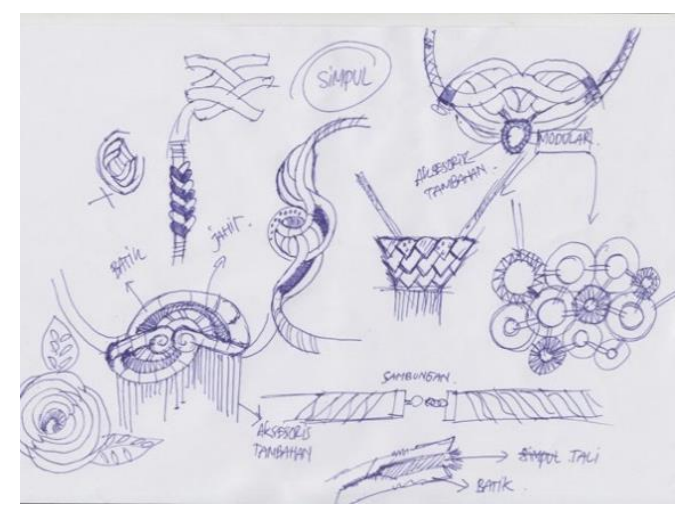

Gambar : 8 (Sebagian sketsa rancangan produk)

Sumber: Sektsa manual Peneliti

Lalu untuk proses terahir dari tahap pertama ini adalah pembuatan klasifikasi bahan dan teknik dari rencana produk yang akan dibuat. Secara spesifik peneliti membuat bagan yang terdapat klasifikasi tahapan teknik dan contoh material yang dipakai, selain itu jenis limbah jenis motif dan warna juga diidentifikasi secara detail. Hal ini ditujukan sebagai dokumentasi proses pembuatan produk agar masing-masing desain dapat diproduksi ulang setelah mendapat respon pasar.

\subsection{Eksperimen Pembuatan Aksesoris sebagai Pilot Project}

Pada tahap ini limbah kain batik yang telah disortir selanjutnya disortir berdasarkan jenis bentuk dan warna yang sesuai dengan konsep awal. Setiap potongan kain disesuaikan dengan desain, dengan memanfaatkan teknik gabungan patchwork dan knot serta aplikasi tambahan dengan memanfaatkan teknik winding dan lilitan benang sebagai variasi. Berikut ini gambar dari hasil ekperimen teknik:

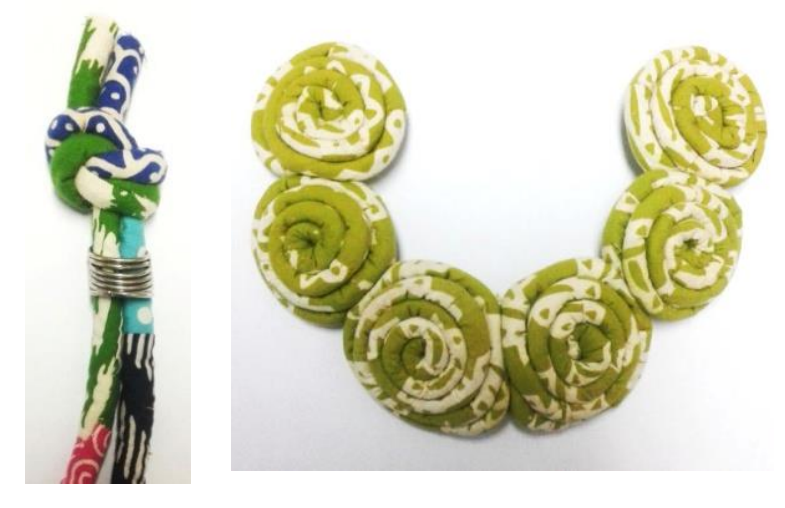

Gambar : 9 (Penerapan teknik patchworkknot dan Penerapan teknik sulam dan gulungan)

Sumber: Peneliti 
Dari hasil eksperimen teknik tersebut, selanjutnya akan diterpakan pada produk aksesoris yang telah direncanakan di awal yaitu berupa kalung, gelang dan sirkam. Prototip dari hasil eksperimen ini akan dijadikan sebagai pilot project atau acuan pengembangan desain lebih lanjut. Namun pada prosesnya terdapat beberapa kendala yang hadir pada saat penyesuaian limbah kain ke dalam desain yaitu:

1. Bentuk sisa potongan yang tidak menentu sehingga seringkali tidak cocok pada penerapan desain yang telah direncanakan.

2. Jenis sisa kain yang bercampur jenis lain sehingga cukup memakan waktu dalam memilah kembali kain jenis katun yang akan diaplikasikan.

3. Beberapa bentuk motif menjadi terdegradasi oleh karena penerapan teknik, namun pada beberapa desain masih dominan terlihat motif khas Garutan.

Pada produk pertama dibawah ini yaitu berupa kalung dan variasi gelang, peneliti ingin menunjukan kesan emosi ceria, muda, dan enerjik. Motif desain yang diaplikasikan yaitu variasi motif dasar geometrik. Prinsip desain yang dipakai yaitu irama yang dihasilkan pada teknik knot, keseimbangan simetris, dan penambahan ring emas sebagai aksen.


Gambar : 10 (Hasil produk 1)

Sumber: Peneliti

Selanjutnya pada produk kedua adalah berupa sirkam, bentuk yang diterapkan kali ini lebih representatif yang memanfaatkan unsur flora. Pemilihan jenis limbah dari segi warna merupakan hal penting dalam pembuatan produk ini.Teknik yang diaplikasikan yaitu gulungan untuk membentuk pola bunga dan sulam jahit untuk membentuk pola daun. Penambahan aksen aksesoris bentuk daun dan biji emas,sedangkan untuk produk ketiga aksen aksesoris yang diterapkan yaitu batu imitasi berwarna hitam. Kedua aksen ini diterapkan pada bagian atas sebagai aksen untuk menambah prinsip kontras dan point of interest.



Gambar : 11 (Proses pembuatan produk 2) Sumber: Peneliti 

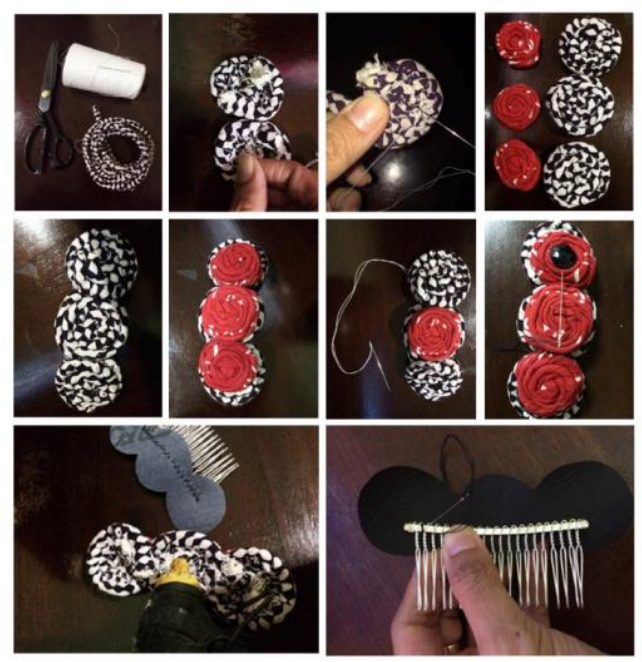

Gambar : 12 (Proses pembuatan variasi produk 2)

Sumber: Peneliti

Lalu pada produk ketiga, peneliti membuat varian lain yaitu berupa gelang. Gelang ini cukup berbeda dengan desain sebelumnya, peneliti memanfaatkan jenis limbah yang sama dalam segi motif dan warna. Teknik yang diaplikasikan yaitu jahit sulam, lilitan benang pada pengembangan produk dan beberapa bandul yang dibungkus dengan kain limbah. Kesan yang ingin ditonjolkan yaitu esklusif dan ceria, oleh karenanya aplikasi yang diterapkan lebih banyak memanfaatkan aksesoris penunjang seperti rantai dan bandul berwarna emas.

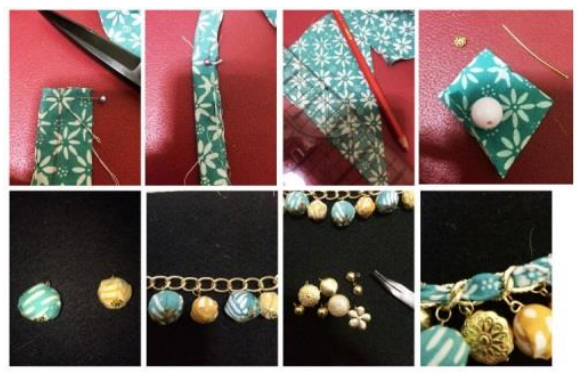

Gambar : 13 (Proses pembuatan produk 3)

Sumber: Peneliti

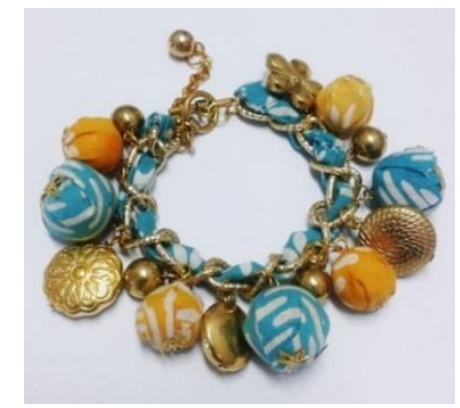

Gambar : 14 (Hasil produk 3)

Sumber: Peneliti

\subsection{Implementasi Produk}

Setelah membuat produk eksperimen yang diperuntukan sebagai pilot project, peneliti meneruskan untuk membuat produk pengembangan untuk uji pasar setelah itu dianalisa berdasarkan target market user. Peneliti memanfaatkan mitra Ayunan Indonesia sebagai brand produk untuk membuka stand produk acara Pasar Seni ITB pada tanggal 23 November 2014. Pasar Seni ITB merupakan acara seni yang diadakan 4 tahun sekali dan merupakan perhelatan acara seni terbesar se Asia Tenggrara. Oleh karenanya peneliti melihat hal ini sebagai kesempatan yang sangat baik dalam mengimplementasikan produk di pasar. Analisa yang dilakukan yaitu mengenai customer behavior yang meliputi keinginan membeli, motif pembelian, dan sikap terhadap produk. Berikut ini adalah dokumentasi suasana acara dan penjualan produk dari pengembangan hasil penelitian: 




Gambar : 15 (Suasana Pameran Produk

Hasil Penelitian)

Sumber: Dokumentasi Peneliti

Analisa pasar dilakukan dengan menduplikasi setiap prototip menjadi 3 pasang, setiap produk lebih diarahakan pada jenis eksplorasi teknik knot dengan dominasi padu padan pada warna. Selama pameran produk hasil penelitian cukup mengundang perhatian pasar, hal ini dapat dilihat dari banyaknya antusiasme pembeli yang ingin memiliki lebih dari satu dalam satu jenis produk. yang paling banyak diminati pasar.

Berikut ini tabel analisa awal dari hasil pameran produk di pasar seni ITB 2014:

\begin{tabular}{|c|c|c|c|c|c|}
\hline No & Produk & $\begin{array}{c}\text { Baha } \\
\text { n } \\
\text { Baku }\end{array}$ & $\begin{array}{c}\text { Aplika } \\
\text { si } \\
\text { teknik }\end{array}$ & $\begin{array}{c}\text { Aplika } \\
\text { si } \\
\text { Warna } \\
\text { dan } \\
\text { Motif } \\
\text { Batik } \\
\text { Garuta } \\
\text { n }\end{array}$ & $\begin{array}{c}\text { Resp } \\
\text { on } \\
\text { Pasar }\end{array}$ \\
\hline 1 & & $\begin{array}{l}\text { Limb } \\
\text { ah } \\
\text { sisa } \\
\text { produ } \\
\text { k baju } \\
\text { anak } \\
\text { dan } \\
\text { bonek }\end{array}$ & $\begin{array}{l}\text { Jahit } \\
\text { dan } \\
\text { knot } \\
\text { dengan } \\
\text { penam } \\
\text { bahan } \\
\text { variasi } \\
\text { rantai }\end{array}$ & $\begin{array}{l}\text { Kombi } \\
\text { nasi } \\
\text { motif } \\
\text { geomet } \\
\text { rik } \\
\text { dengan } \\
\text { unsur } \\
\text { flora. }\end{array}$ & $\begin{array}{l}\text { Sanga } \\
\text { t baik }\end{array}$ \\
\hline
\end{tabular}

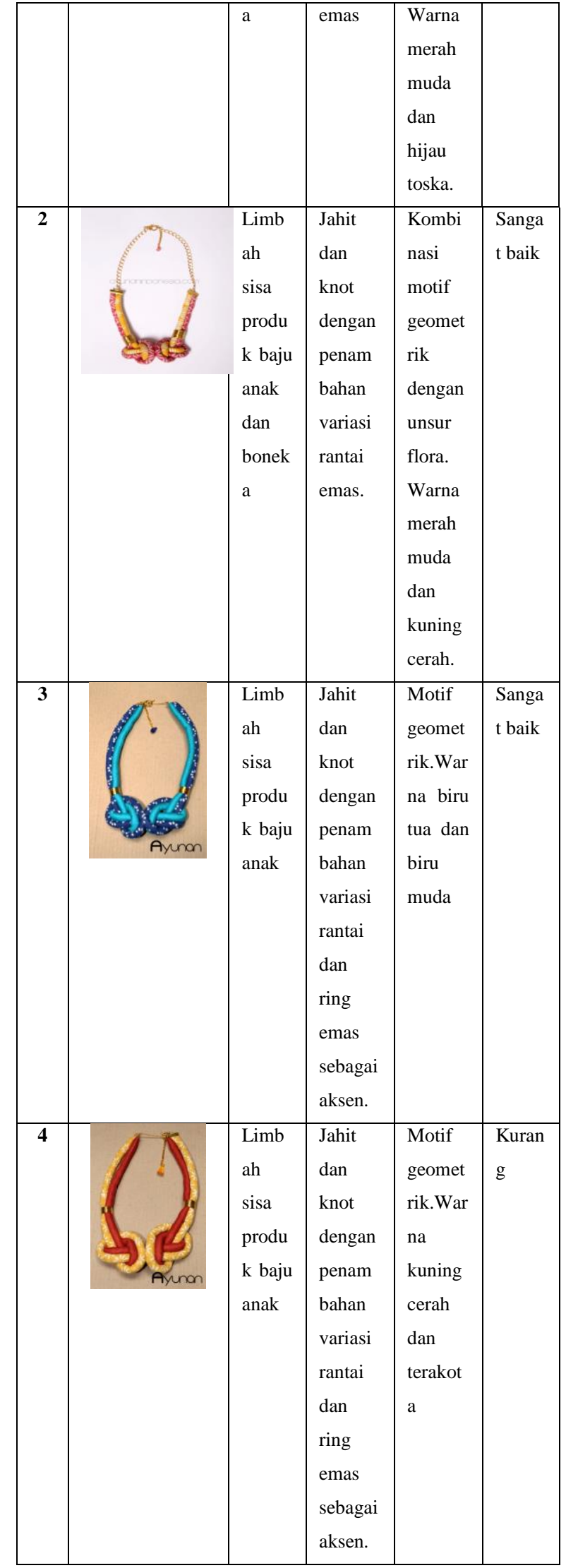




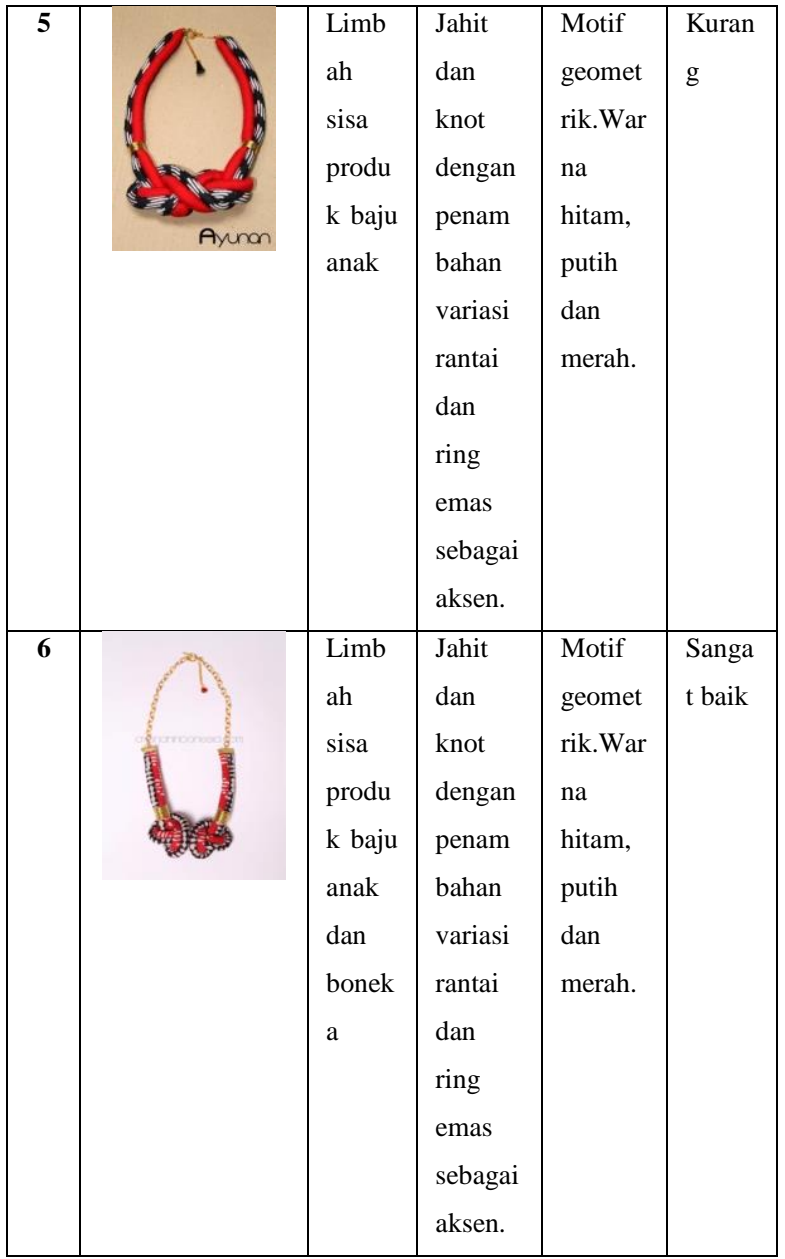

Tabel 1: Analisa pasar sebagai implementasi produk

\section{KESIMPULAN DAN SARAN}

Penelitian yang sudah dilakukan ini perlu adanya tahap lanjutan terutama dalam pengembangan teknik dan pengembangan jenis produk yang diaplikasikan. Eksplorasi penggabungan material lokal lain perlu dipertimbangkan untuk memperkuat identitas lokal, mengingat pada beberapa hasil eksplorasi bentuk motif sudah terdegradasi.

Oleh karena jumlah produksi Batik Garutan terus makin meningkat maka secara tidak langsung jumlah limbah yang dihasilkan pun pasti meningkat, hal ini menjadi peluang besar untuk dapat dijadikan produk kreatif alternatif lain sekaligus mereduksi jumlah limbah yang berdampak buruk kepada lingkungan. Permasalahannya pada beberapa daerah objek survei seperti di Garut, belum banyak orang yang tertarik mengolah limbah atau sisa kain batik menjadi barang siap pakai yang bernilai lebih. Dan pada prosesnya diperlukan sumber daya manusia yang lebih banyak, terutama dalam proses pemilihan limbah kain yang sesuai dengan rencana desain.

Diperlukan program lanjutan berupa pengabdian kepada masyarakat agar target UKM yang diberdayakan semakin luas. Eksperimen produk yang dihasilkan sebagai pilot project perlu dikaji ulang berkaitan dengan teknik untuk lebih diarahkan secara sederhana agar dapat diaplikasikan dengan mudah. Selanjutnya perlu pendekatan berkala kepada UKM untuk dapat mengerti trend fashion yang sedang berkembang saat ini agar model produk selalu up to date.

Berkaitan dengan analisa pasar, produk hasil penelitian ini sudah menunjukan apresiasi yang sangat baik oleh masyarakat, namun diperlukan adanya perlindungan Hak Cipta agar produk yang telah ada dipasarkan mendapatkan pengakuan dan tidak mudah ditiru oleh produsen lain. 


\section{Daftar Pustaka}

1. Black, Sandy. 2011. Eco-Chic, The Fashion Paradox. Black Dog Publishing, Limited London, UK

2. Chijiwa, Hideaki, 1987. Color Harmony, A Guide to Create Color Combination. Rockport publisher, Rockport. Massachusetts

3. Calderin, Jay.2011. Fashion Design Essentials. Quayside Publishing Group. USA

4. Djomena, Nian. 1990. Ungkapan Sehelai Batik. Jakarta: Jambatan.

5. Dofa, Anesia Aryunda. 1996.Batik Indonesia. Jakarta: Golden Terayon Press.

6. Johnson, Garth. 2009. Ideas For Creative Reuse. Quayside Publishing Group. USA

7. Hady, Devi Candraditya. 2012. Eksplorasi Sisa Pertenunan Serat Sutera Dengan Teknik Makrame Pada Produk Fashion. Jurnal Seni Rupa dan Desain ITB

8. Kustanti,Hemi, dkk. 2002. Pendidikan Keterampilan. Gramedia Pustaka

9. Nurdalia,Ida. 2006. Kajian Dan Analisis Peluang Penerapan pProduksi Bersih Pada Usaha Kecil Batik Cap.Semarang: Tesis Program Magister Ilmu Lingkungan Program Pascasarjana Universitas Diponegoro
10. Rizali,Nanang; Jusuf,Herman; Ken Atik, Saftiyanigsih. 2003. Batik Garut: Kajian Bentuk dan Warna. Wacana Seni Rupa Jurnal Seni Rupa dan Desain vol. 3,6.

11. Sastrawijaya, A. Tresna. 2000. Pencemaran Lingkungan. Jakarta : Rineka Cipta. 